\title{
EUROPEJSKIE UGRUPOWANIE WSPÓŁPRACY TERYTORIALNEJ A WSPÓŁPRACA ZAGRANICZNA JEDNOSTEK SAMORZĄDU TERYTORIALNEGO
}

\section{Wstęp}

Europejskie Ugrupowanie Współpracy Terytorialnej (EUWT) jest nowym instrumentem prawnym umożliwiającym prowadzenie efektywniejszej i skuteczniejszej współpracy zagranicznej przez jednostki samorządu terytorialnego. Celem artykułu jest przybliżenie tej instytucji oraz szczegółowe opisanie procedury rejestracji EUWT, a także określenie jego znaczenia dla prowadzonej współpracy zagranicznej przez jednostki samorządu terytorialnego.

Przyjęcie 5 lipca 2006 roku rozporządzenia nr 1082/2006 Parlamentu Europejskiego i Rady w sprawie europejskiego ugrupowania współpracy terytorialnej (dalej: Rozporządzenie EUWT) ${ }^{66}$ stanowi przełomowe wydarzenie w zakresie ram prawnych dotyczących współpracy terytorialnej w Unii Europejskiej oraz bez wątpienia jej ewolucji. EUWT jest pierwszym w historii integracji Unii prawnym instrumentem regulującym tę dziedzinę, natomiast wydanie norm prawnych na poziomie rozporządzenia sytuuje współpracę terytorialną w samym centrum procesu integracji, gdzie do tej pory płaszczyzna ta była zaniedbywana przez europejskiego prawodawcę. ${ }^{67}$

Doktorant w Zakładzie Prawa Europejskiego Wydziału Prawa Uniwersytetu w Białymstoku, podinspektor ds. współpracy zagranicznej w Gabinecie Prezydenta Miasta w Urzędzie Miejskim w Słupsku.

66 Rozporządzenie (WE) nr 1082/2006 Parlamentu Europejskiego i Rady z dnia 5 lipca 2006 r. w sprawie europejskiego ugrupowania współpracy terytorialnej (EUWT), Dz.U. UE, L 210/19, tryb dostępu: http://eur-lex.europa. eu/LexUriServ/LexUriServ.do?uri=OJ:L:2006:210:0019:0024:PL:PDF, dnia 01.12.2012 r.

67 Komitet Regionów, Europejskie Ugrupowanie Współpracy Terytorialnej, analiza opracowana przez Grupę Europejskich Studiów Politycznych pod przewodnictwem profesora Nicolasa Levrata w ramach programu badań Komitetu Regionów pod nadzorem Działu Analiz Politycznych, Badań i Międzyinstytucjonalnego Planowania Legislacyjnego (Gianluca Spinaci, Jarosław Lotarski i Lucia Cannellini) oraz sekretariatu Komisji COTER (Damian Lluna Taberner), tryb dostępu: http://cor.europa.eu/en/Archived/Documents/8af77b7b-a510-4d1b-9f8e-576a771ecb76.pdf, dnia 01.12.2012 r. 
Samorządy lokalne i regionalne w Unii Europejskiej napotykały wiele problemów w zakresie współpracy międzynarodowej. ${ }^{68} \mathrm{~W}$ celu ominięcia tych przeszkód Komisja Europejska podjęła działania umożliwiające stworzenie, na poziomie Unii Europejskiej, grup współpracy posiadających osobowość prawną.

14 lipca 2004 roku Komisja Europejska przyjęła projekt rozporządzenia Parlamentu Europejskiego i Rady ustanawiającego europejskie ugrupowanie współpracy transgranicznej (EUWT). ${ }^{69}$ Projekt ten był konsultowany z wieloma organami i środowiskami, ${ }^{70} \mathrm{w}$ tym z najbardziej zainteresowanym - Komitetem Regionów. Organ doradczy Parlamentu Europejskiego, Komisji i Rady opowiedział się pozytywnie za ideą utworzenia EUWT, proponując w swojej opinii parę zmian legislacyjnych. ${ }^{71}$ Komitet Regionów zwrócił szczególną uwagę, że w ramach EUWT współpraca powinna być możliwa w trzech płaszczyznach współpracy międzynarodowej: transgranicznej, międzyregionalnej i transnarodowej, a nie tylko transgranicznej, jak zaproponowała w swoim projekcie Komisja Europejska. ${ }^{72}$ Ponadto Komitet zalecił zapis ,EUWT wykonuje zadania powierzane przez członków lub przez osoby trzecie, za jego zgoda i zgodnie z niniejszym rozporzadzeniem”, aby w przyszłości EUWT mogło ubiegać się o środki finansowe z Unii Europejskiej. ${ }^{73}$

\section{Charakterystyka Europejskiego Ugrupowania Współpracy Terytorialnej}

Europejskie Ugrupowanie Współpracy Terytorialnej jest nową instytucją posiadającą osobowość prawną. ${ }^{74}$ Osobowość prawną uzyskuje z momentem wpisania do rejestru lub publikacji ${ }^{75}$ w państwie członkowskim, gdzie ma znajdować się siedziba danego EUWT. Członkowie EUWT informują o rejestracji lub publikacji, a także o statucie zainteresowane państwa członkowskie oraz Komitet Regionów. ${ }^{76} \mathrm{~W}$ każdym z państw członkowskich Unii Europejskiej EUWT posiada zdolność prawną

68 Wśród problemów można wyróżnić w szczególności: odmienne systemy bankowe, różnice w regulacjach prawnych odnoszących się do zasad rachunkowości i księgowości. Szerzej: Komitet Regionów, Europejskie Ugrupowanie Współpracy Terytorialnej, s. 57-62.

Projekt rozporządzenia Parlamentu Europejskiego i Rady ustanawiającego Europejskie Grupy Współpracy Transgranicznej (EGWT), COM(2004) 496 final, tryb dostępu: http://www.mrr.gov.pl/rozwoj_regionalny/ poziom_miedzynarodowy/polityka_spojnosci_po_2013/dokumenty_i_akty_prawne/Documents/36857c40757f4733b83335a13bd4358317_projekt_rozp_egwt_091104.pdf, dnia 01.12.2012 r.

70 Projekt rozporządzenia został zaopiniowany przez Komitet Ekonomiczno - Społeczny, Dz.U. C 255 z 14 października 2005, str. 76 oraz Komitet Regionów, Dz.U. C 71 z 22 marca 2005.

71 Opinia Komitetu Regionów w sprawie wniosku dotyczącego rozporządzenia Parlamentu Europejskiego i Rady ustanawiającego europejskie ugrupowanie współpracy transgranicznej (EUWT), Dz.U. UE C 71 z 22 marca 2005 roku, s. 46, tryb dostępu: http://eur-lex.europa.eu/LexUriServ/LexUriServ.do?uri=OJ:C:2005:071:0046:0053:PL:PDF, dnia 01.12.2012 r. Ibidem, s. 49.

Ibidem, s. 51.

Zgodnie z art. 1 ust. 3 Rozporządzenia EUWT.

W zależności od tego, która czynność następuje wcześniej.

Art. 5 ust. 1 Rozporządzenia EUWT. 
i zdolność do czynności prawnych o najszerszym zakresie przyznawanym osobom prawnym na mocy prawa krajowego tego państwa członkowskiego. ${ }^{77}$

Członkami mogą być państwa członkowskie Unii Europejskiej, władze regionalne i lokalne oraz podmioty prawa publicznego, ${ }^{78}$ a także stowarzyszenia składające się z podmiotów należących do jednej lub kilku z wymienionych wcześniej kategorii. Podmioty będące członkami EUWT działają w granicach kompetencji przyznanych przez właściwe dla nich prawo krajowe. EUWT składa się z członków położonych na terytorium przynajmniej dwóch państw członkowskich. ${ }^{79}$

Głównym zadaniem funkcjonowania europejskiego ugrupowania współpracy terytorialnej, które pokrywa się z celem powołania tego podmiotu, jest ułatwianie i upowszechnianie współpracy transgranicznej, transnarodowej lub międzyregionalnej między jego członkami wyłącznie w celu wzmocnienia spójności ekonomicznej i społecznej..$^{80}$ Ponadto do zadań EUWT może należeć realizacja projektów dofinansowanych z Europejskiego Funduszu Społecznego, Europejskiego Funduszu Rozwoju Regionalnego oraz Funduszu Spójności przeznaczonych przez Unię Europejską na współpracę terytorialną. ${ }^{81}$ Spośród szczególnych celów europejskiego ugrupowania współpracy terytorialnej, zawartych w art. 7 Rozporządzenia EUTW, wymienić możemy także prowadzenie strategicznej współpracy, a także może pełnienie roli narzędzia projektu współpracy. ${ }^{82}$

W związku z ponadnarodowym charakterem europejskiego ugrupowania terytorialnego powstaje problem właściwości prawa właściwego. Kwestę tę reguluje art. 2 Rozporządzenia EUWT, który określa prawo właściwe i normy kolizyjne. Zgodnie z normami prawnymi zawartymi w tym artykule europejskie ugrupowanie współpracy terytorialnej podlega przepisom Rozporządzenia EUWT, konwencji i statutowi. ${ }^{83}$ Natomiast $\mathrm{w}$ przypadkach nieuregulowanych lub w przypadkach

77 Szerzej o podmiotowości prawnej EUWT: Europejskie Ugrupowanie Współpracy Terytorialnej, Komitet Regionów 2007, s. 79-84, tryb dostępu: http://cor.europa.eu/en/archived/documents/8af77b7b-a510-4d1b-9f8e-576a771ecb76.pdf, dnia 01.12.2012 r.

78 „Podmiot prawa publicznego” oznacza każdy podmiot: ustanowiony w szczególnym celu zaspokajania potrzeb w interesie ogólnym, które nie mają charakteru przemysłowego ani handlowego; posiadający osobowość prawną; oraz finansowany w przeważającej części przez państwo, jednostki samorządu terytorialnego lub inne podmioty prawa publicznego; albo taki, którego zarząd podlega nadzorowi ze strony tych podmiotów; albo taki, w którym ponad połowa członków organu administrującego, zarządzającego lub nadzorczego została wyznaczona przez państwo, jednostki samorządu terytorialnego lub inne podmioty prawa publicznego. (Na podstawie art. 1 ust. 9 akapit drugi Dyrektywy nr 2004/18/WE Parlamentu Europejskiego i Rady z dnia 31 marca 2004 roku w sprawie koordynacji procedur udzielania zamówień publicznych na roboty budowlane, dostawy i usługi, Dz.U. UE L 134 z 30 kwietnia 2004 roku, str. 114, źródło: http://eur-lex.europa.eu/LexUriServ/LexUriServ. do?uri=CONSLEG:2004L0018:20080101:PL:PDF, z 1 grudnia 2012 roku.

79 Art. 3 Rozporządzenia EUWT.

80 Art. 1 ust. 2 Rozporządzenia EUWT.

81 Warto podkreślić, że współpraca terytorialna jest jednym z trzech celów funduszy strukturalnych i Funduszu Spójności w okresie programowania na lata 2007-2013. (art. 3 ust. 2 lit. c Rozporządzenie Rady (WE) nr 1083/2006 z dnia 11 lipca 2006 r. ustanawiające przepisy ogólne dotyczące Europejskiego Funduszu Rozwoju Regionalnego, Europejskiego Funduszu Społecznego oraz Funduszu Spójności i uchylające rozporządzenie (WE) nr 1260/1999), Dz.U. UE, L 210 z 31 lipca 2006 r., s. 37.

82 Komitet Regionów, Europejskie Ugrupowanie Współpracy Terytorialnej, s. 3.

83 Uchwalonymi przez członków założycieli europejskiego ugrupowania współpracy terytorialnej. 
tylko częściowej regulacji zawartej przez Rozporządzenie EUWT właściwym jest prawo państwa członkowskiego, na terytorium którego znajduje się statutowa siedziba ugrupowania. ${ }^{84}$

W przypadkach, gdy zgodnie z prawem Unii Europejskiej, bądź międzynarodowym prawem prywatnym, konieczne jest dokonanie wyboru prawa, europejskie ugrupowanie współpracy terytorialnej traktuje się jako podmiot państwa członkowskiego, gdzie ma swoją statutową siedzibę..$^{85}$

\section{Rejestracja EUWT}

Po przybliżeniu w sposób syntetyczny genezy nowego instrumentu w płaszczyźnie współpracy terytorialnej w Unii Europejskiej, głównym zadaniom oraz prawa właściwego dla europejskiego ugrupowania terytorialnego, przejdźmy do scharakteryzowania procedury rejestracji takiego podmiotu na przykładzie Polski, czyli takiego przypadku, gdzie statutowa siedziba europejskiego ugrupowania współpracy terytorialnej będzie miała miejsce na terytorium Rzeczypospolitej Polskiej.

Regulacje odnoszące się do rejestracji europejskiego ugrupowania współpracy terytorialnej zostały zawarte w Rozporządzeniu EUWT oraz w ustawie o europejskim ugrupowaniu współpracy terytorialnej. ${ }^{86} \mathrm{~W}$ przypadkach nieuregulowanych rozporządzeniem oraz ustawą stosuje się odpowiednio przepisy o stowarzyszeniach.

Pierwszym krokiem w celu powołania europejskiego ugrupowania współpracy terytorialnej jest uchwalenie jednogłośnie przez członków konwencji. Minimalny zakres przedmiotowy konwencji został określony w art. 8 Rozporządzenia EUWT. Zgodnie z zapisami tego przepisu konwencja musi zawierać:

- określenie nazwy europejskiego ugrupowania współpracy terytorialnej oraz jego statutowej siedziby w jednym z państw członkowskich Unii Europejskiej zgodnie z prawem, którego został utworzony przynajmniej jeden z jego członków;

- określenie zasięgu terytorialnego, na którym może wykonywać swoje zadania $^{87}$;

- cele i zadania europejskiego ugrupowania współpracy terytorialnej;

- czas funkcjonowania oraz warunki rozwiązania;

- listę członków europejskiego ugrupowania współpracy terytorialnej;

Art. 2 ust. 1 Rozporządzenia EUWT.

Ibidem.

Ustawa z dnia 7 listopada 2008 roku o europejskim ugrupowaniu współpracy terytorialnej, Dz.U. z 2008 r. Nr 218, poz. 1390. Przepisy ustawy wykonują postanowienia rozporządzenia (WE) nr 1082/2006 Parlamentu Europejskiego i Rady z dnia 5 lipca 2006 r. w sprawie europejskiego ugrupowania współpracy terytorialnej (EUWT) (Dz. Urz. UE L 210 z 31.07.2006, str. 19).

Należy pamiętać, że zasięg terytorialny nie może być większy niż właściwość miejscowa członka ugrupowania. 
- określenie prawa właściwego do celów interpretacji i stosowania konwencji ${ }^{88}$;

- określenie odpowiednich uzgodnień określających wzajemne uznawanie, w tym kontrolę finansową;

- procedurę wprowadzania zmian do konwencji, zgodnie z obowiązującymi przepisami prawa Unii Europejskiej i krajowych porządków prawnych.

Kolejnym etapem w procedurze powoływania do życia europejskiego ugrupowania współpracy terytorialnej jest jednomyślne przyjęcie statutu zgodnie z postanowieniami już przyjętej konwencji. Statut musi zawierać poza postanowieniami konwencji następujące elementy ${ }^{89}$ :

- określać sposób działania organów europejskiego ugrupowania współpracy terytorialnej i ich kompetencji, a także liczbę przedstawicieli poszczególnych członków w odpowiednich organach; ${ }^{90}$

- określać procedury decyzyjne EUWT;

- określić język lub języki robocze;

- zawierać uzgodnienia dotyczące funkcjonowania europejskiego ugrupowania współpracy terytorialnej, ze szczególnym uwzględnieniem zarządzania personelem, procedury rekrutacji oraz form zatrudnienia;

- podział wkładów finansowych członków oraz zasad rachunkowych i budżetowych;

- uzgodnienia dotyczące odpowiedzialności finansowej członków; ${ }^{91}$

- określać organy odpowiedzialne za wyznaczenie niezależnych audytów zewnętrznych;

- zapisy określające procedury wprowadzania zmian do statutu. ${ }^{92}$

Następnie każdy członek europejskiego ugrupowania współpracy terytorialnej przesyła zgodnie z prawem krajowym właściwemu organowi kopię proponowanej konwencji i statutu z informacją o woli przystąpienia do ugrupowania. W terminie nie dłuższym niż 3 miesiące organ podejmuję decyzję w tym zakresie. ${ }^{93}$ Po uzyska-

Prawem tym jest prawo państwa członkowskiego, w którym znajduje się siedziba statutowa europejskiego ugrupowania współpracy terytorialnej.

89 Zgodnie $z$ art. 9 Rozporządzenia EUWT.

90 Zgodnie z art. 10 Rozporządzenia EUWT, europejskie ugrupowanie współpracy terytorialnej musi mieć następujące organy: zgromadzenie składające się z przedstawicieli członków oraz dyrektora - reprezentującego ugrupowanie i działającego w jego imieniu. Zgodnie z wolą członków, statut może przewidywać dodatkowe organy, z zastrzeżeniem określenia dla nich wyraźnych kompetencji.

$91 \quad$ Zgodny z zapisami zawartymi w art. 12 ust. 2 Rozporządzenia EUWT.

92 Zmiany statutu muszą być zgodne z obowiązkami określonymi w art. 4 i 5 Rozporządzenia EUWT.

93 Państwo członkowskie nie wydaje zgody na przystąpienie do ugrupowania, gdy uważa ono, że takie uczestnictwo, w tym uprawnienia i obowiązki przyszłego członka, nie sa zgodne z niniejszym rozporządzeniem lub z prawem krajowym, lub że uczestnictwo to nie jest uzasadnione ze względu na interes publiczny lub porządek publiczny tego państwa członkowskiego. W takim przypadku państwo członkowskie uzasadnia powody nieudzielenia zgody. 
niu zgody członek wysyła dokument wyrażający zgodę na przystąpienie do ugrupowania podmiotowi, który będzie odpowiadał za rejestrację ugrupowania.

Zgodnie z polskim ustawodawstwem uchwałę o przystąpieniu do europejskiego ugrupowania współpracy terytorialnej Rzeczypospolitej Polskiej podejmuje Rada Ministrów w drodze uchwały, w której wyznacza ministra właściwego ${ }^{94}$ do reprezentowania Rzeczypospolitej Polskiej w ugrupowaniu, do którego przystąpiła. Natomiast uchwałę o przystąpieniu do ugrupowania jednostki samorządu terytorialnego podejmuje organ stanowiący tej jednostki bezwzględną większością głosów ustawowego składu. ${ }^{95}$ Uchwała organu stanowiącego oraz decyzja o przystąpieniu do ugrupowania podmiotu prawa publicznego wchodzi w życie po uzyskaniu zgody w drodze decyzji wydanej przez ministra właściwego do spraw zagranicznych. ${ }^{96}$

Po uzyskaniu zgody na przystąpienie od państw członkowskich Unii Europejskiej do ugrupowania przez wszystkich członków, upoważniona osoba przez członków ugrupowania dokonuje zgłoszenia do Rejestru ${ }^{97}$ Europejskich Ugrupowań Współpracy Terytorialnej. Zgodnie z wymogami zawartymi w $§ 5$. rozporządzenia ministra spraw zagranicznych w sprawie sposobu prowadzenia Rejestru dla Europejskich Ugrupowań Współpracy Terytorialnej oraz art. 9 ust. 2 ustawy o europejskich ugrupowaniu współpracy terytorialnej upoważniona osoba wraz ze zgłoszeniem dołącza następujące dokumenty:

- konwencję i statut ugrupowania;

- uchwały albo decyzje członków ugrupowania o przyjęciu statutu;

- upoważnienia do dokonywania czynności związanych z wpisaniem ugrupowania do rejestru;

- zgody na przystąpienie każdego z członków wydane przez państwo członkowskie.

Po wypełnieniu tych wszystkich formalności przez dane ugrupowanie współpracy terytorialnej, konwencja i statut publikowany jest w Dzienniku Urzędowym Rzeczypospolitej Polskiej „Monitor Polski B”.

94 Na podstawie ustawy z dnia 4 września 1997 roku o działach administracji rządowej, Dz.U. z 2007 r. Nr 65, poz. 437, z późn. zm.

95 Art. 5 ust. 1 ustawy z dnia 7 listopada 2008 roku o europejskim ugrupowaniu współpracy terytorialnej, Dz.U. z 2008 r. Nr 218, poz. 1390.

96 Minister właściwy do spraw zagranicznych wydaje zgodę w drodze decyzji w uzgodnieniu z ministrem właściwym do spraw wewnętrznych, ministrem właściwym do spraw finansów publicznych oraz ministrem właściwym do spraw rozwoju regionalnego $w$ terminie 3 miesięcy od otrzymania uchwały lub decyzji.

97 Rejestr prowadzony jest zgodnie z Rozporządzeniem Ministra Spraw Zagranicznych z dnia 17 czerwca 2009 roku w sprawie sposobu prowadzenia Rejestru Europejskich Ugrupowań Współpracy Terytorialnej, Dz.U. z 2009 r. Nr 1005, poz. 875, tryb dostępu: http://www.nettax.pl/dzienniki/du/2009/105/poz.875.htm, dnia 01.12.2012 r. 
Obecnie w Unii Europejskiej funkcjonuje 31 Europejskich Ugrupowań Współpracy Terytorialnej. ${ }^{98}$ Utworzone one zostały w przeważającej większości na terenach przygranicznych. Wynika to ze specyfiki EUWT. Ze względu na trudną i długą procedurę utworzenia ugrupowania, decydują się na nią w większości przypadków te podmioty, które mają już długoletnią współpracę i traktują ugrupowanie jako kolejny etap wzmożonej współpracy.

Lista europejskich ugrupowań współpracy terytorialnej (stan na 03.122012 r.).

\begin{tabular}{|c|c|c|c|c|}
\hline Lp. & $\begin{array}{l}\text { Nazwa Europejskiego Ugrupowania } \\
\text { Współpracy Terytorialnej }\end{array}$ & siedziba & $\begin{array}{c}\text { Państwa } \\
\text { członkowskie }\end{array}$ & Data założenia \\
\hline 1. & Eurometropool Lille - Kortrijk-Tournai & Lille (Francja) & Francja / Belgia & $\begin{array}{l}22 \text { stycznia } 2008 \\
\text { (publikacja) }\end{array}$ \\
\hline 2. & $\begin{array}{l}\text { Ister - Granum Europejskiego } \\
\text { Ugrupowania Współpracy Terytorialnego } \\
\text { Ltd }\end{array}$ & $\begin{array}{l}\text { Esztergom } \\
\text { (Węgry) }\end{array}$ & $\begin{array}{l}\text { Węgry I } \\
\text { Słowacja }\end{array}$ & $\begin{array}{l}12 \text { listopada } \\
2008 \\
\text { (rejestracja) }\end{array}$ \\
\hline 3. & $\begin{array}{l}\text { Europejskie Stowarzyszenie } \\
\text { na rzecz Współpracy Terytorialnej Galicji } \\
\text { i północnej Portugalii. } \\
\text { (GNP AECT) }\end{array}$ & Vigo (Hiszpania) & $\begin{array}{l}\text { Hiszpania / } \\
\text { Portugalia }\end{array}$ & $\begin{array}{l}23 \text { października } \\
2008 \\
\text { (rejestracja) }\end{array}$ \\
\hline 4. & $\begin{array}{l}\text { Europejskie Ugrupowanie Współpracy } \\
\text { Terytorialnej Amphictyony miast } \\
\text { partnerskich i obszarów Morza } \\
\text { Śródziemnego. }\end{array}$ & Ateny (Grecja) & $\begin{array}{l}\text { Grecja / Włochy } \\
\text { / Francja/ Cypr }\end{array}$ & $\begin{array}{l}1 \text { grudnia } 2008 \\
\text { (rejestracja) }\end{array}$ \\
\hline 5. & $\begin{array}{l}\text { Ung-Tisza-Túr-Sajó (Hernád-Bódva- } \\
\text { Szinva) EUWT z o.o. } \\
\text { (UTTS) }\end{array}$ & Miskole (Węgry) & $\begin{array}{l}\text { Słowacja / } \\
\text { Węgry }\end{array}$ & $\begin{array}{l}15 \text { stycznia } 2009 \\
\text { (publikacja) }\end{array}$ \\
\hline 6. & $\begin{array}{l}\text { Europejskie Ugrupowanie Współpracy } \\
\text { Terytorialnej Karst-Bodva }\end{array}$ & $\begin{array}{l}\text { Turňa nad } \\
\text { Bodvou } \\
\text { (Słowacja) }\end{array}$ & $\begin{array}{l}\text { Słowacja / } \\
\text { Węgry }\end{array}$ & $\begin{array}{l}11 \text { lutego } 2009 \\
\text { (rejestracja) }\end{array}$ \\
\hline 7. & $\begin{array}{l}\text { Europejskie Ugrupowanie Współpracy } \\
\text { Terytorialnej Duero-Douro }\end{array}$ & $\begin{array}{l}\text { Trabanca } \\
\text { (Hiszpania) }\end{array}$ & $\begin{array}{l}\text { Hiszpania / } \\
\text { Portugalia }\end{array}$ & $\begin{array}{l}21 \text { marca } 2009 \\
\text { (rejestracja) }\end{array}$ \\
\hline 8. & $\begin{array}{l}\text { Europejskie Ugrupowanie Współpracy } \\
\text { Zachodnie Vlaanderen/Flandre- } \\
\text { Dunkierka-Côte d'Opale }\end{array}$ & $\begin{array}{l}\text { Dunkierka } \\
\text { (Francja) }\end{array}$ & Francja / Belgia & $\begin{array}{l}25 \text { marca } 2009 \\
\text { (rejestracja) }\end{array}$ \\
\hline 9. & EUWT ArchiMed & $\begin{array}{l}\text { Taormina } \\
\text { (Włochy) }\end{array}$ & $\begin{array}{l}\text { Włochy / Cypr } \\
\text { / Hiszpania / } \\
\text { Grecja }\end{array}$ & $\begin{array}{l}6 \text { marca } 2011 \\
\text { (rejestracja) }\end{array}$ \\
\hline 10. & EUWT Mediterranean Pyrenees & \begin{tabular}{|l|} 
Toulouse \\
(Francja)
\end{tabular} & $\begin{array}{l}\text { Francja / } \\
\text { Hiszpania }\end{array}$ & $\begin{array}{l}25 \text { sierpnia } 2009 \\
\text { (rejestracja) }\end{array}$ \\
\hline 11. & EUWT Eurodistrict Strasburg-Ortenau & $\begin{array}{l}\text { Strasburg } \\
\text { (Francja) }\end{array}$ & $\begin{array}{l}\text { Francja / } \\
\text { Niemcy }\end{array}$ & $\begin{array}{l}25 \text { stycznia } 2010 \\
\text { (rejestracja) }\end{array}$ \\
\hline 12. & $\begin{array}{l}\text { Europejskie Ugrupowanie Współpracy } \\
\text { Terytorialnej ZASNET (ZASNET) }\end{array}$ & $\begin{array}{l}\text { Braganca } \\
\text { (Portugalia) }\end{array}$ & $\begin{array}{l}\text { Portugalia / } \\
\text { Hiszpania }\end{array}$ & $\begin{array}{l}19 \text { marca } 2010 \\
\text { (publikacja) }\end{array}$ \\
\hline
\end{tabular}

98 Lista europejskich ugrupowań współpracy terytorialnej opracowana na postawie rejestru przez Komitet Regionów, tryb dostępu http://portal.cor.europa.eu/egtc/en-US/Documents/2012-10-03\%20list\%20of\%20existing\%20 EGTC_EN.pdf, dnia 08.12.2012 r. 
Rafał Kuligowski

\begin{tabular}{|c|c|c|c|c|}
\hline 13. & $\begin{array}{l}\text { Europejskie Ugrupowanie Współpracy } \\
\text { Terytorialnej Szpital Cerdanya (AECT } \\
\text { HC) }\end{array}$ & $\begin{array}{l}\text { Puigcerda } \\
\text { (Hiszpania) }\end{array}$ & $\begin{array}{l}\text { Hiszpania / } \\
\text { Francja }\end{array}$ & $\begin{array}{l}26 \text { kwietnia } 2010 \\
\text { (rejestracja) }\end{array}$ \\
\hline 14. & $\begin{array}{l}\text { EUWT „wielki program INTERREG } \\
\text { Region” }\end{array}$ & Metz (Francja) & $\begin{array}{l}\text { Francja / } \\
\text { Niemcy/ } \\
\text { Luksemburg / } \\
\text { Belgia }\end{array}$ & $\begin{array}{l}29 \text { marca } 2010 \\
\text { (rejestracja) }\end{array}$ \\
\hline 15. & Eurodistrikt Saarmoselle (SaarMoselle) & $\begin{array}{l}\text { Sarreguemines } \\
\text { (Francja) }\end{array}$ & \begin{tabular}{|l|} 
Francja / \\
Niemcy \\
\end{tabular} & $\begin{array}{l}6 \text { maja } 2010 \\
\text { (rejestracja) }\end{array}$ \\
\hline 16. & $\begin{array}{l}\text { Europejskie Ugrupowanie Współpracy } \\
\text { Terytorialnej ABAÚJ-ABAÚJBAN }\end{array}$ & Miskole (Węgry) & $\begin{array}{l}\text { Węgry / } \\
\text { Słowacja }\end{array}$ & $\begin{array}{l}11 \text { czerwca } 2010 \\
\text { (rejestracja) }\end{array}$ \\
\hline 17. & EUWT Pons Danubii & $\begin{array}{l}\text { Komarno } \\
\text { (Słowacja) }\end{array}$ & $\begin{array}{l}\text { Słowacja / } \\
\text { Węgry }\end{array}$ & $\begin{array}{l}16 \text { grudnia } 2010 \\
\text { (rejestracja) }\end{array}$ \\
\hline 18. & EUWT Banat-Triplex (EN) & $\begin{array}{l}\text { Moraholm } \\
\text { (Węgry) }\end{array}$ & $\begin{array}{l}\text { Węgry / } \\
\text { Rumunia }\end{array}$ & $\begin{array}{l}5 \text { stycznia } 2011 \\
\text { (rejestracja) }\end{array}$ \\
\hline 19. & EUWT Arrabona & Gyor (Węgry) & $\begin{array}{l}\text { Węgry / } \\
\text { Słowacja }\end{array}$ & $\begin{array}{l}7 \text { czerwca } 2011 \\
\text { (rejestracja) }\end{array}$ \\
\hline 20. & EUWT „Linieland van Waas en Hulst” & $\begin{array}{l}\text { Sint - Gillis - } \\
\text { Waas (Belgia) } \\
\end{array}$ & \begin{tabular}{|l|} 
Belgia / \\
Holandia \\
\end{tabular} & $\begin{array}{l}15 \text { czerwca } 2011 \\
\text { (rejestracja) }\end{array}$ \\
\hline 21. & $\begin{array}{l}\text { EUWT Euroregion Tirolo-Alto Adige- } \\
\text { Trentino }\end{array}$ & $\begin{array}{l}\text { Bolzano / Bozen } \\
\text { (Włochy) }\end{array}$ & $\begin{array}{l}\text { Włochy / } \\
\text { Austria }\end{array}$ & $\begin{array}{l}13 \text { września } 2011 \\
\text { (rejestracja) } \\
\text { Zawarte na okres } \\
15 \text { lat. } \\
\end{array}$ \\
\hline 22. & $\begin{array}{l}\text { Gminy: Gmina Gorycji (Włochy), Mestna } \\
\text { Občina Nova Gorica (Słowenia) oraz } \\
\text { Občina Sempeter-Vrtojba (Słowenia) }\end{array}$ & Gorizia (Włochy) & $\begin{array}{l}\text { Włochy I } \\
\text { Słowenia }\end{array}$ & $\begin{array}{l}15 \text { września } 2011 \\
\text { (rejestracka) }\end{array}$ \\
\hline 23. & EUWT Pirineus - Cerdanya & $\begin{array}{l}\text { Saillagouse } \\
\text { (Francja) }\end{array}$ & $\begin{array}{l}\text { Francja / } \\
\text { Hiszpania }\end{array}$ & $\begin{array}{l}22 \text { września } 2011 \\
\text { (rejestracka) }\end{array}$ \\
\hline 24. & $\begin{array}{l}\text { Europejskie Ugrupowanie Współpracy } \\
\text { Terytorialnej „Espacio Portalet” }\end{array}$ & $\begin{array}{l}\text { Sabiñánigo } \\
\text { (Hiszpania) }\end{array}$ & $\begin{array}{l}\text { Hiszpania / } \\
\text { Francja }\end{array}$ & $\begin{array}{l}3 \text { czerwca } 2011 \\
\text { (rejestracja) }\end{array}$ \\
\hline 25. & EUWT Rába-Duna-Vág & $\begin{array}{l}\text { Tatabánya } \\
\text { (Węgry) }\end{array}$ & $\begin{array}{l}\text { Węgry / } \\
\text { Słowacja }\end{array}$ & $\begin{array}{l}10 \text { grudnia } 2011 \\
\text { (rejestracja) }\end{array}$ \\
\hline 26. & EUWT Euroregion Aquitaine-Euskadi & $\begin{array}{l}\text { Hendaye } \\
\text { (Francja) }\end{array}$ & \begin{tabular}{|l|} 
Francja / \\
Hiszpania \\
\end{tabular} & $\begin{array}{l}12 \text { grudnia } 2011 \\
\text { (rejestracja) }\end{array}$ \\
\hline 27. & EUWT Poarta Europa & $\begin{array}{l}\text { Nyiradony } \\
\text { (Węgry) }\end{array}$ & $\begin{array}{l}\text { Wegry / } \\
\text { Rumunia }\end{array}$ & $\begin{array}{l}7 \text { maja } 2012 \\
\text { (rejestracja) }\end{array}$ \\
\hline 28. & EUWT BODROGKÖZI & Miskolc (Węgry) & $\begin{array}{l}\text { Węgry / } \\
\text { Słowacja }\end{array}$ & $\begin{array}{l}11 \text { kwietnia } 2012 \\
\text { (rejestracja) }\end{array}$ \\
\hline 29. & EUWT Novohrad-Nógrád & $\begin{array}{l}\text { Salgótarján } \\
\text { (Węgry) }\end{array}$ & $\begin{array}{l}\text { Węgry / } \\
\text { Słowacja }\end{array}$ & $\begin{array}{l}21 \text { grudnia } 2011 \\
\text { (rejestracja) }\end{array}$ \\
\hline 30. & EUWT Pannon & Pécs (Węgry) & $\begin{array}{l}\text { Węgry / } \\
\text { Słowenia }\end{array}$ & $\begin{array}{l}28 \text { marca } 2012 \\
\text { (rejestracja) }\end{array}$ \\
\hline 31. & $\begin{array}{l}\text { POLI EFXINI EUWT - Europejska Sieć } \\
\text { Miast na rzecz Ekorozwoju }\end{array}$ & $\begin{array}{l}\text { Acharnes Attica } \\
\text { (Grecja) }\end{array}$ & $\begin{array}{l}\text { Grecja / Cypr / } \\
\text { Bułgaria }\end{array}$ & $\begin{array}{l}2 \text { sierpnia } 2012 \\
\text { (rejestracja) } \\
\text { Zawarte na okres } \\
25 \text { lat } \\
\end{array}$ \\
\hline
\end{tabular}

Jak możemy zaobserwować z powyższej listy, EUWT tworzone są w przeważającej większości między regionami transgranicznymi - wynika to z większej liczby płaszczyzn współpracy między tymi regionami. Utworzenie ugrupowania bez wątpienia ułatwia realizację wspólnych projektów, w tym infrastrukturalnych i inwe- 
stycyjnych. Najwięcej EUWT utworzonych zostało przez regiony hiszpańskie, francuskie, portugalskie i węgierskie. Z listy przygotowanej przez Komitet Regionów wynika, że z roku na rok liczba tworzonych ugrupowań stale rośnie. Warto zwrócić uwagę, że poza dwoma wyjątkami, ugrupowania zakładane są na czas nieokreślony.

\section{EUWT w Polsce}

Współpraca zagraniczna jednostek samorządu terytorialnego w Polsce, mimo słabych regulacji prawnych, jest prowadzona od wielu lat bardzo efektywnie..$^{99}$ Jako przykład może posłużyć współpraca województwa wielkopolskiego z Gruzją ${ }^{100}$ czy 25-letnie doświadczenie we współpracy w ramach tzw. Trójporozumienia Carlisle Flensburg - Słupsk. ${ }^{101}$

W Polsce do tej pory odnotowano jeden przykład starań o powołanie europejskiego ugrupowania współpracy terytorialnej, były to 2 regiony z Polski i po jednym z Czech i Słowacji - województwo opolskie i śląskie (Polska), Kraj Morawsko-Śląski (Czechy) oraz Samorządowy Kraj Żyliński (Słowacja). Ubieganie się o powołanie ugrupowania przez te regiony rozpoczęło się w 2009 roku i po trzyletniej pracy, 4 grudnia 2012 roku powołano pierwsze Europejskie Ugrupowanie Współpracy Terytorialnej - TRITIA, ${ }^{102}$ do którego należą polskie regiony. ${ }^{103}$ Jest to niewątpliwie początek działalności w ramach europejskich ugrupowań współpracy terytorialnej dla polskich jednostek samorządu terytorialnego.

\section{Podsumowanie}

Europejskie ugrupowanie współpracy terytorialnej jest nowym instrumentem umożliwiającym regionom Unii Europejskiej podejmowanie współpracy transgranicznej, transnarodowej i międzyregionalnej. Dzięki posiadaniu przez ugrupowanie osobowości prawnej zainteresowane pomioty mają możliwość uniknięcia problemów, z jakimi musiałyby się zmierzyć w prowadzeniu dotychczasowej współpracy ze swoimi międzynarodowymi partnerami. Problemy wynikały głównie z różnic regulacji prawnych, zawierania umów, reprezentacji nawiązanych partnerstw czy różnych systemów bankowych i polityki finansowej. Bez wątpienia nowy instrument jest przełomowym wydarzeniem w historii europejskiej polityki regionalnej.

Szerzej na temat współpracy międzynarodowej jednostek samorządu terytorialnego w świetle prawa polskiego: M. Woźniak, Współpraca międzynarodowa jednostek samorządu terytorialnego w świetle prawa polskiego i standardów międzynarodowych, „Samorząd Terytorialny” 2005, nr 4, s. 12-26. 
Mimo skomplikowanej procedury tworzenia oraz względnie dużych formalności nałożonych na prowadzenie ugrupowań w Unii Europejskiej, można zauważyć coraz większe zainteresowanie powołaniem europejskich ugrupowań współpracy terytorialnej. W tym narzędziu samorządy lokalne i regionalne nie tylko widzą szansę na pogłębienie istniejącej współpracy, ale także możliwości pozyskania dodatkowych środków z funduszy europejskich na realizację wspólnych projektów. W mojej ocenie kwestią czasu jest, aby europejskie ugrupowanie stało się podstawową formą współpracy międzynarodowej Unii Europejskiej. Praktyka pokazuje, że utworzone ugrupowania usprawniają współpracę oraz umożliwiają realizację dotąd ciężkich do zrealizowania projektów.

W mojej ocenie, europejskie ugrupowanie współpracy terytorialnej będzie spełniało funkcję efektywnego narzędzia współpracy między regionami. Szczególnego znaczenia nabierze w przypadkach wieloletniej współpracy między partnerami na płaszczyźnie międzynarodowej. To szczególnie w tych przypadkach będzie ono miało największe zastosowanie. Ugrupowanie stanie się kolejnym etapem współpracy. Moim zdaniem, samorządy najpierw będą nawiązywały porozumienia partnerskie, realizowały wspólne projekty, a w momencie, gdy ich współpraca się pogłębi, będą powoływać na tej bazie ugrupowania. Instrument ten zapełnia lukę w europejskiej współpracy terytorialnej, dając nowe możliwości i nowy wymiar tej polityce. 


\section{EUROPEAN GROUPING OF TERRITORIAL COOPERATION AND INTERNATIONAL COOPERATION OF LOCAL GOVERNMENTS}

The European Grouping of Territorial Cooperation (EGTC) is a new instrument for carrying out international cooperation by the institutions concerned, local and regional authorities. EGTC are appointed by decree of 5 July 2006 of Regulation No 1082/2006 of the European Parliament and of the Council on a European grouping of territorial cooperation (Dz. U. UE, L 210/19), and the laws of the Member States of the European Union. Without a doubt, this instrument allows a new and more effective cross-border, transnational and interregional cooperation to be run. Currently, the European Union has registered 32 EGTC's, including one in Poland. Although the current number of EGTC's generated is only small, which seems to result from a complex registration process, I think it will soon be a fundamental instrument for co-operation of local and regional authorities of the European Union.

Keywords:

International cooperation, grouping of territorial cooperation, region 